\title{
Identifying Key Research Objectives to Make European Forests Greener for Bats
}

\begin{abstract}
Danilo Russo ${ }^{1,2 *}$, Geoff Billington ${ }^{3}$, Fabio Bontadina ${ }^{4,5}$, Jasja Dekker ${ }^{6}$, Markus Dietz $^{7}$, Suren Gazaryan ${ }^{8}$, Gareth Jones ${ }^{2}$, Angelika Meschede ${ }^{9}$, Hugo Rebelo ${ }^{2,10}$, Guido Reiter ${ }^{11}$, Ireneusz Ruczyński ${ }^{12}$, Laurent Tillon ${ }^{13}$ and Peter Twisk ${ }^{14}$

${ }^{1}$ Wildlife Research Unit, Laboratorio di Ecologia Applicata, Dipartimento di Agraria, Università degli Studi di Napoli Federico II, Napoli, Italy, ${ }^{2}$ School of Biological Sciences, University of Bristol, Bristol, UK, ${ }^{3}$ Greena Ecological Consultancy, Cullompton, UK, ${ }^{4}$ Urban Ecology \& Wildlife Research, Zurich, Switzerland, ${ }^{5}$ Biodiversity and Conservation Biology, Swiss Federal Institute for Forest, Snow and Landscape Research, Birmensdorf, Switzerland, ${ }^{6}$ Jasja Dekker Dierecologie, Arnhem, Netherlands, ${ }^{7}$ Institute of Animal Ecology and Nature Education, Laubach, Germany, ${ }^{8}$ UNEP/EUROBATS, Bonn, Germany, ${ }^{9}$ Formerly affiliated with Institute of Zoology II, University of Erlangen-Nuremberg, Erlangen, Germany, ${ }^{10}$ InBIO-Centro de Investigação em Biodiversidade e Recursos Genéticos da Universidade do Porto, Vairão, Portugal, " ${ }^{11}$ Austrian Coordination Center for Bat Conservation and Research, Leonding, Austria, ${ }^{12}$ Mammal Research Institute PAS, Białowieża, Poland, ${ }^{13}$ Office National des Forêts, Direction des Forêts et des Risques Naturels, Paris, France, ${ }^{14}$ Regelink Ecologie \& Landschap, Mheer, Netherlands
\end{abstract}

\section{OPEN ACCESS}

Edited by:

Rodrigo Medellin,

National Autonomous University of

Mexico, Mexico

Reviewed by:

Mariana M. Vale,

Federal University of Rio de Janeiro,

Brazil

Tigga Kingston,

Texas Tech University, USA

*Correspondence:

Danilo Russo

danrusso@unina.it

Specialty section:

This article was submitted to

Conservation,

a section of the journal

Frontiers in Ecology and Evolution

Received: 29 March 2016

Accepted: 11 July 2016

Published: 22 July 2016

Citation:

Russo D, Billington G, Bontadina F,

Dekker J, Dietz M, Gazaryan S,

Jones $G$, Meschede A, Rebelo $H$, Reiter G, Ruczyński I, Tillon $L$ and

Twisk P (2016) Identifying Key

Research Objectives to Make European Forests Greener for Bats.

Front. Ecol. Evol. 4:87.

doi: 10.3389/fevo.2016.00087
Bats are a biodiverse mammal order providing key ecosystem services such as pest suppression, pollination, and seed dispersal. Bats are also very sensitive to human actions, and significant declines in many bat populations have been recorded consequently. Many bat species find crucial roosting and foraging opportunities in European forests. Such forests have historically been exploited by humans and are still influenced by harvesting. One of the consequences of this pressure is the loss of key habitat resources, often making forests inhospitable to bats. Despite the legal protection granted to bats across Europe, the impacts of forestry on bats are still often neglected. Because forest exploitation influences forest structure at several spatial scales, economically viable forestry could become more sustainable and even favor bats. We highlight that a positive future for bat conservation that simultaneously benefits forestry is foreseeable, although more applied research is needed to develop sound management. Key future research topics include the detection of factors influencing the carrying capacity of forests, and determining the impacts of forest management and the economic importance of bats in forests. Predictive tools to inform forest managers are much needed, together with greater synergies between forest managers and bat conservationists.

Keywords: bat conservation, Chiroptera, ecosystem services, forestry, pest suppression

\section{INTRODUCTION}

Bats are one of the most diverse mammal groups featuring over 1300 species worldwide (Fenton and Simmons, 2014; Russo and Jones, 2015). They provide crucial biodiversity services such as pest suppression, pollination, and seed dispersal, so their keystone roles in many ecosystems have important ecological and economic consequences (Kunz et al., 2011; Maine and Boyles, 2015). Therefore, declines in bat populations may have detrimental cascade effects on biodiversity. Bats 
are extraordinary in many aspects: they show low reproductive output, exceptional longevity, preference for specific roosting or foraging habitats, aggregations in large numbers, high sensitivity to climate and disturbance, and high positions in trophic webs (e.g., Altringham, 2011). Habitat specialization increases extinction risk in bats (Safi and Kerth, 2004). These traits make bats especially sensitive to anthropogenic changes and explain why these mammals are effective bioindicators (Jones et al., 2009; Russo and Jones, 2015; Van der Meij et al., 2015). Nowadays many bat species are jeopardized by human activities, including the loss or alteration of roosts and foraging grounds, pesticide use, the impact of wind turbines and overhunting or direct persecution (Voigt and Kingston, 2016).

Although bats often roost in caves or buildings, many species inhabit forests and exhibit wing morphology and echolocation calls tailored to life in this cluttered habitat (Norberg and Rayner, 1987; Schnitzler and Kalko, 2001; Russo, 2012). Many bat species roost in trees, which provide a variety of cavity types offering a range of thermal conditions (Kunz and Lumsden, 2003; Dietz and Hörig, 2011). Migratory bats often use forests to reproduce, stopover or hibernate (Cryan and Veilleux, 2007). Forested corridors also provide landmarks for commuting and promote connectivity between otherwise fragmented populations (Hein et al., 2009). Unlike bat species that roost in underground sites or buildings, which often congregate in large numbers at single sites, forest bats mostly roost in small numbers scattered across large forest patches (Russo et al., 2005), with some remarkable exceptions of large colonies (Boye and Dietz, 2005). Forest bats frequently switch roosts, either to maintain social relationships (Kerth et al., 2011), to develop cognitive maps of alternative roost locations (Russo et al., 2005) or to decrease parasite burden (Bartonička and Gaisler, 2007). Roost requirements may differ greatly among species (Ruczyński and Bogdanowicz, 2005; Russo, 2012). Suitable cavities are rare in forests, and are mostly found in large broadleaved trees-especially veteran, decaying or standing dead trees. To preserve even a small bat population, large numbers of suitable trees are needed (Russo et al., 2005). Bat boxesartificial shelters for bats-may help, but by no means replace natural cavities (Mering and Chambers, 2014). Finally, forests provide bats with essential foraging habitats (Lacki et al., 2007), e.g., clearings, spaces above the canopy, woodland edges, and substrate (vegetation or the ground) from which prey can be gleaned.

Forests have vital economic and social importance for humans, as a source of timber as well as other products (FAO, 2015). Logging forests for timber production still produces profound changes in habitat structure, influencing key variables at several spatial scales such as height, size, quality, spatial distribution, and density of trees (Ruczyński et al., 2010; Law et al., 2016; Figure 1). Concerns over forest safety, fire risk, timber productivity, and pest spread have led foresters to remove trees important for bats, such as dead or defective trees (Russo et al., 2010). Commercial forest exploitation leads also to a loss of structural heterogeneity (Russo, 2012; Law et al., 2016), affecting bats (Froidevaux et al., 2016) as well as other wildlife (Russo et al., 2011). For such reasons, the needs of forestry and nature conservation often conflict.

Most European forests have been exploited by humans for centuries and are still strongly influenced by harvesting (Kirby and Watkins, 2015). Forests and other wooded land account for over $43 \%$ of Europe's land surface. Over recent decades, land abandonment and afforestation of non-forest land have led to a moderate increase in forest cover in Europe, but this trend seems to have stabilized (European Environment Agency, 2016). Over 96\% of Europe's forests have been modified or created by people as semi-natural forests or plantations, while primary and near-primary forests are rare and keep shrinking (WWF, 2001). For example, the Polish government's plans to conduct massive logging to counter an outbreak of European spruce bark (Ips typographus) in the Białowieża Primeval Forest have raised great concern among conservationists as this would fatally undermine ecological functions in this unique biotope (Chylarecki and Selva, 2016; Michalak, 2016).While natural forests are structurally heterogeneous, and often comprise uneven-aged stands characterized by a high variability in tree size and abundant deadwood (Bauhus et al., 2009), European forests are often (60\%) even-aged, and show reduced deadwood volumes as a result of management. At a landscape scale, conversion of land to agriculture, urban expansion, and development of roads and other infrastructures are progressively fragmenting such forests (European Environment Agency, 2016). The implications for biodiversity are critical: in $27 \mathrm{EU}$ countries, the conservation status of $76 \%$ of forest habitats and $60 \%$ of forest species of European interest was classified as unfavorable in 2007-2012 (European Environment Agency, 2016). Only 12.2\% of European forests are protected (FAO, 2015).

Europe is home to 53 bat species (Table 1), 46 of which occur in EU countries. Although only 14 bat species present on the continent are classified either as globally threatened or near threatened in the IUCN Red List (three are categorized as data deficient and five do not feature in the list), many species show decreasing population trends (www.iucn.org, accessed on 30 May 2016). Moreover, the IUCN assessment has so far neglected recently discovered cryptic species (e.g., Mayer and von Helversen, 2001; Bogdanowicz et al., 2015).

Most European bats use forests for roosting and/or foraging (Table 1) and segregate niches by exploiting different habitats within forest. Some species roost in live or decaying trees (e.g., Myotis bechsteinii), whereas others (Barbastella barbastellus) mostly rely on snags (e.g., Russo et al., 2004; Dietz, 2013). Species such as Plecotus auritus glean prey from foliage in dense vegetation (Entwistle et al., 1996); others mostly hunt along forest edges or in clearings, either on the wing (e.g., Nyctalus noctula, Rachwald, 1992; Pipistrellus pygmaeus, Bartonička et al., 2008) or by perch-hunting (Rhinolophus ferrumequinum; Duverge and Jones, 2003). Some bats may also exploit the open space above the canopy (Barbastella barbastellus, Sierro, 1999). Forest interiors may be seasonally (R. ferrumequinum; Duverge and Jones, 2003) or permanently (M. bechsteinii; Dietz, 2013) important for foraging bats.

If trends in European forest management are not reversed, we foresee a bleak future for bat species. How can the 

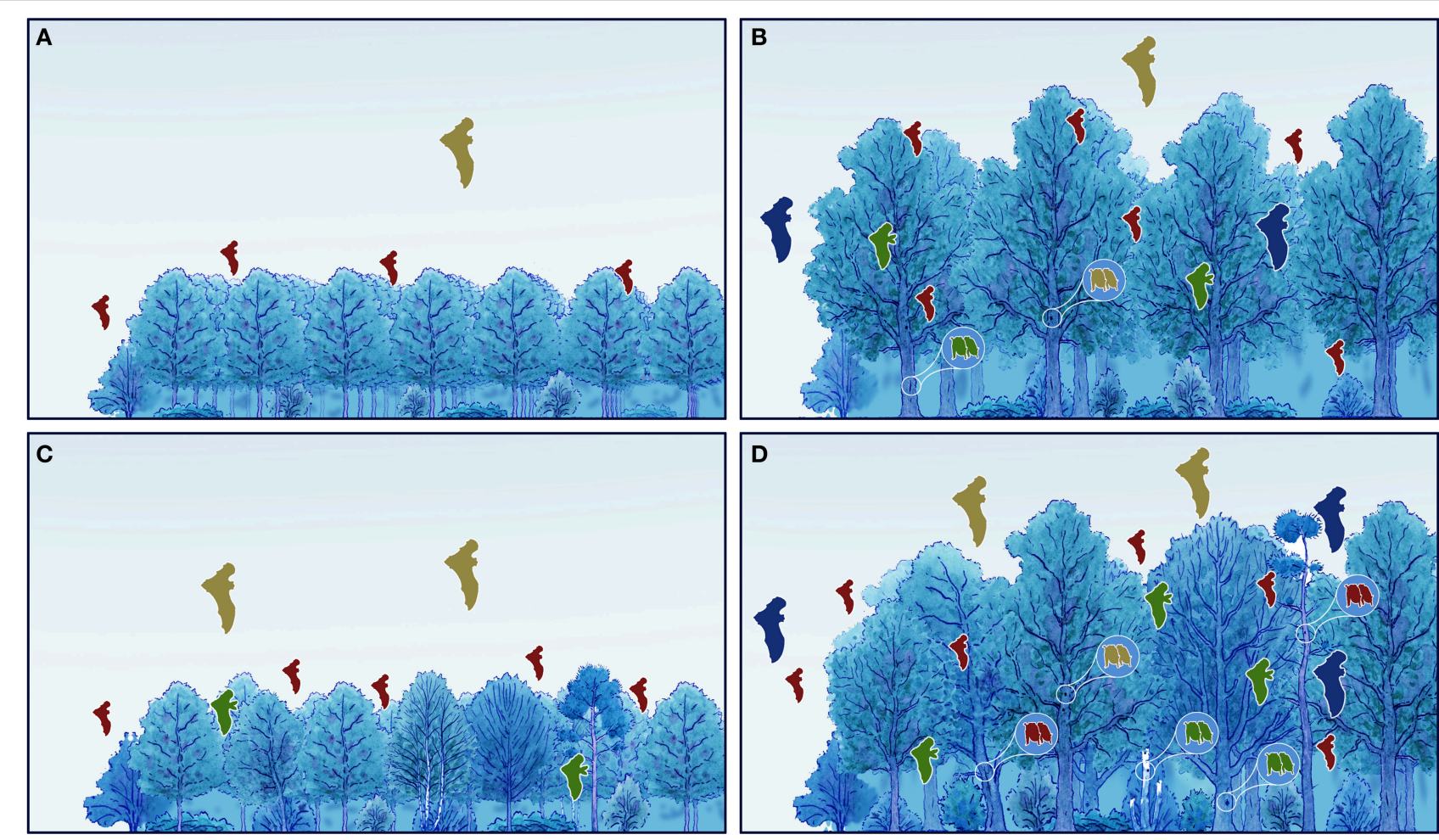

FIGURE 1 | Schematic illustration of the effects of forest age and structural variation (both profoundly influenced by the type of management applied) on the value of forest for bats. The latter increases both for feeding and roosting with increasing age and structural variation. (A) Young, structurally homogeneous forest; (B) Old, structurally homogeneous forest; (C) Young heterogeneous forest; (D) Old heterogeneous forest. Flying bats represent foraging, bats in circles represent roosting. The colors represent different guilds (brown, aerial hawkers, e.g., Nyctalus spp.; green, gleaners, e.g., Plecotus auritus; red, small-size edge foragers, e.g., Pipistrellus spp.; blue, large-size edge foragers, e.g., Eptesicus serotinus).

gap between forest management and the needs of forest dwelling bats be reconciled? In this paper we present the outcome of a workshop held in the Netherlands in November 2015 in which we identified knowledge gaps and collected suggestions for future research directions needed to balance forest productivity and bat conservation in European forestry practice. Although much is known about the basic ecology of some forest-dwelling species (e.g., Dietz, 2013), we highlighted urgent research necessary to identify the best strategies to conserve bats in managed forests. The following considerations focus on Europe, and especially on the EU countries, but most of them can be extended to other temperate regions.

\section{HOW DOES FOREST MANAGEMENT AFFECT BATS?}

Forestry alters forest stand age and composition, both key elements in determining foraging and roosting opportunities for bats (Figure 1). Undoubtedly, the effects of forestry on bat populations are multifaceted and complex, and depend on whether management practices reduce the quality and quantity of spatial features needed by bats.
Frequently, management will affect different bat species in different ways by influencing the availability of roosting or foraging habitat. Thinning may make forest more suitable for foraging by edge or open space specialists, but be detrimental for species that hunt in clutter (Patriquin and Barclay, 2003; Cox et al., 2016). Clearcutting may increase forest fragmentation and force bats that roost in forest but forage elsewhere to cover longer commuting distances to meet both roosting and foraging needs (Popa-Lisseanu et al., 2009).

Felling of a single roost tree can kill or harm individuals directly. Killing individuals may have legal implications, particularly if protected species are affected, although population-level effects are unknown. While appropriate measures could be planned to mitigate direct mortality, such as avoiding forest operations at critical times of year (e.g., the reproductive and hibernation seasons), the spatial patterns of habitat change resulting from logging may have considerable implications for bat conservation and in theory can be planned ad hoc to promote it. So far, forest operations in Europe have typically increased stand evenness and decreased the density of decaying or dead trees (European Environment Agency, 2016), jeopardizing bat survival by reducing the availability of key resources. 
TABLE 1 | List of bat species occurring in the 50 countries of Europe according to EUROBATS.

\begin{tabular}{|c|c|c|}
\hline Family/Species & Roosting & Foraging \\
\hline \multicolumn{3}{|l|}{ PTEROPODIDAE } \\
\hline Rousettus aegyptiacus (Geoffroy, 1810)* & & $\bullet$ \\
\hline \multicolumn{3}{|l|}{ EMBALLONURIDAE } \\
\hline \multicolumn{3}{|l|}{ Taphozous nudiventris (Cretzschmar, 1830)* } \\
\hline \multicolumn{3}{|l|}{ RHINOLOPHIDAE } \\
\hline Rhinolophus blasii (Peters, 1866) & & $\bullet$ \\
\hline Rhinolophus euryale (Blasius, 1853) & & $\bullet$ \\
\hline Rhinolophus ferrumequinum (Schreber, 1774) & & $\bullet$ \\
\hline Rhinolophus hipposideros (Bechstein, 1800) & $\bullet$ & $\bullet$ \\
\hline Rhinolophus mehelyi (Matschie, 1901) & & $\bullet$ \\
\hline \multicolumn{3}{|l|}{ VESPERTILIONIDAE } \\
\hline Barbastella barbastellus (Schreber, 1774) & $\bullet$ & $\bullet$ \\
\hline Barbastella darjelingensis (Hodgson, 1855)* & $?$ & $?$ \\
\hline Eptesicus bottae (Peters, 1869)* & $?$ & $?$ \\
\hline Eptesicus nilssonii (Keyserling and Blasius, 1839) & $\bullet$ & $\bullet$ \\
\hline Eptesicus anatolicus (Felten, 1971) & & $\bullet$ \\
\hline Eptesicus isabellinus (Temminck, 1840) & $\bullet$ & $\bullet$ \\
\hline Eptesicus serotinus (Schreber, 1774) & & $\bullet$ \\
\hline Hypsugo savii (Bonaparte, 1837) & & $\bullet$ \\
\hline Myotis alcathoe (von Helversen and Heller, 2001) & $\bullet$ & $\bullet$ \\
\hline Myotis aurascens (Kuzyakin, 1935) & & $\bullet$ \\
\hline Myotis bechsteinii (Kuhl, 1817) & $\bullet$ & $\bullet$ \\
\hline Myotis blythii (Tomes, 1857) & $\bullet$ & $\bullet$ \\
\hline Myotis brandtii (Eversmann, 1845) & $\bullet$ & $\bullet$ \\
\hline \multicolumn{3}{|l|}{ Myotis capaccinii (Bonaparte, 1837) } \\
\hline Myotis dasycneme (Boie, 1825) & $\bullet$ & \\
\hline Myotis daubentonii (Kuhl, 1817) & $\bullet$ & $\bullet$ \\
\hline Myotis emarginatus (Geoffroy, 1806) & $\bullet$ & $\bullet$ \\
\hline Myotis escalerai (Cabrera, 1904) & $\bullet$ & $\bullet$ \\
\hline Myotis hajastanicus (Argyropulo, 1939)* & $?$ & $?$ \\
\hline Myotis myotis (Borkhausen, 1797) & $\bullet$ & $\bullet$ \\
\hline Myotis mystacinus (Kuhl, 1817) & $\bullet$ & $\bullet$ \\
\hline Myotis nattereri (Kuhl, 1817) & $\bullet$ & $\bullet$ \\
\hline Myotis nipalensis (Dobson, 1871)* & $?$ & $?$ \\
\hline \multicolumn{3}{|l|}{ Myotis punicus (Felten, 1977) } \\
\hline Myotis schaubi (Kormos, 1934)* & & $?$ \\
\hline Nyctalus azoreum (Thomas, 1901) & $\bullet$ & $?$ \\
\hline Nyctalus lasiopterus (Schreber, 1780) & $\bullet \bullet$ & $\bullet$ \\
\hline Nyctalus leisleri (Kuhl, 1817) & $\bullet$ & $\bullet$ \\
\hline Nyctalus noctula (Schreber, 1774) & $\bullet$ & $\bullet$ \\
\hline Otonycteris hemprichii (Peters, 1859) & & $\bullet$ \\
\hline Pipistrellus hanaki (Hulva and Benda, 2004) & $\bullet$ & $\bullet$ \\
\hline Pipistrellus kuhlii (Kuhl, 1817) & $\bullet$ & $\bullet$ \\
\hline Pipistrellus maderensis (Dobson, 1878) & & $\bullet$ \\
\hline Pipistrellus nathusii (Keyserling and Blasius, 1839) & $\bullet$ & $\bullet$ \\
\hline Pipistrellus pipistrellus (Schreber, 1774) & $\bullet$ & $\bullet$ \\
\hline Pipistrellus pygmaeus (Leach, 1825) & $\bullet$ & $\bullet$ \\
\hline Plecotus auritus (Linnaeus, 1758) & $\bullet$ & $\bullet$ \\
\hline Plecotus austriacus (Fischer, 1829) & $\bullet$ & $\bullet$ \\
\hline Plecotus kolombatovici (Dulic, 1980) & & $\bullet$ \\
\hline
\end{tabular}

(Continued)
TABLE 1 | Continued

\begin{tabular}{|c|c|c|}
\hline Family/Species & Roosting & Foraging \\
\hline Plecotus macrobullaris (Kuzyakin, 1965) & & $\bullet$ \\
\hline Plecotus sardus (Mucedda et al., 2002) & & $\bullet ?$ \\
\hline Plecotus teneriffae (Barrett-Hamilton, 1907) & & $\bullet$ \\
\hline Vespertilio murinus (Linnaeus, 1758) & $\bullet$ & \\
\hline \multicolumn{3}{|l|}{ MINIOPTERIDAE } \\
\hline Miniopterus pallidus (Thomas, 1907) & & $\begin{array}{l}\text { - (forest } \\
\text { edge) }\end{array}$ \\
\hline Miniopterus schreibersii (Kuhl, 1817) & & $\begin{array}{l}\text { - (forest } \\
\text { edge) }\end{array}$ \\
\hline \multicolumn{3}{|l|}{ MOLOSSIDAE } \\
\hline Tadarida teniotis (Rafinesque, 1814) & & $\begin{array}{l}\text { - (over } \\
\text { canopy) }\end{array}$ \\
\hline
\end{tabular}

Roosting and foraging preferences after Dietz and Kiefer (2014). Filled circles indicate the frequency of forest use by bats for foraging and / or roosting as follows: none, never; •, occasionally; ••, frequently; ?, unknown/unclear. Species only occurring in countries outside the European Union are marked with an asterisk. The 50 European countries are those listed by the Nations Online Project (http://www.nationsonline.org/oneworld/europe.htm).

Large-scale harvesting or thinning of woodland may lead to roost loss and induce changes in the availability of foraging habitat. Changes in forest structure caused by logging may increase the extent of edges or clearings, favoring bat species that use edge habitats, while affecting core habitat specialists detrimentally. Harvesting regimes that influence habitat availability as well as prey diversity or abundance may affect foraging success, body condition, survival, and reproductive success, translating into fitness consequences that affect demographic trends. Whether such effects are positive or not depends on the management choices adopted.

\section{FOREST MANAGEMENT AND THE EU LEGAL FRAMEWORK ON BAT PROTECTION}

Bats are legally protected in the EU (corresponding to ca. $43 \%$ of European continent's landmass) and their deliberate killing or destruction of their habitat are legal offenses. The Habitats Directive enlists all species in Annex IV and 13 species under Annex II. Conserving Annex II species requires the designation of Special Areas of Conservation (The Council of European Communities, 1992). All member States must take measures to establish a system of strict protection for bats.

Most European states participate into Bern Convention and the UNEP/EUROBATS Agreement and therefore have binding obligations to protect all bat species within their territories. EUROBATS (2009) has emphasized the significance of forest operations for bat conservation, and promoted the development of guidelines on bat-friendly forestry practices.

In all cases the relevant international legal regulations have to be implemented under national law, but the interpretation in particular of Article 12 of the Habitats Directive, and the measures to fulfill the obligations vary strongly across the EU. Article 12 prohibits the deliberate capture, killing or disturbance 
of bats particularly during breeding, hibernation, and migration. Deterioration or destruction of breeding or roosting sites is also forbidden (EU Commission, 2007).

Increasing forestry contributions to maintain and enhance biodiversity is one of the targets of the 2020 EU Biodiversity Strategy to fulfill commitments to the Convention on Biological Diversity. Action 12 of the strategy makes provisions to integrate biodiversity measures in forest management plans, which will be implemented into national legislation and regulations. Nevertheless, bats are often disregarded when it comes to forestry practices in reality.

For instance, although the Habitat Directive prohibits any deliberate killing of bats or deterioration of their habitats, this is seldom applied to forestry operations. According to the Guidance document (EU Commission, 2007) "deliberate" actions are those undertaken with knowledge of the relevant legislation (from general information delivered to the public) that will most likely harm a species, either with intention, or, if not, with conscious acceptance of the foreseeable results of the action.

Thus, it is necessary to alert foresters about the legislation that applies to bats and their habitats. Information about the importance of forests and trees for bats has been distributed in some European countries, including national and multinational guidance. In Germany, recommendations for forest managers were published in 2000 following a nationwide 3-year research and development project on bats in forests (Meschede and Heller, 2000; Meschede et al., 2002) with a short version (Meschede et al., 2001) available in eight languages. In the Netherlands, a brochure about the importance of trees and forests for bats was issued in 2003 and in the UK several guidelines are available (Anonymous, 2005; Forestry Commission Scotland and Scottish Natural Heritage, 2009).

However, impacts on bats are still often neglected. European, as well as national legal obligations are regularly not complied with in forest management, and destruction of important bat forest habitats or roosts by logging still occurs.

\section{KNOWLEDGE GAPS AND RESEARCH NEEDS ON BATS AND FORESTRY}

There are few studies on the impacts of forestry on bats in Europe, and good practice examples including post-operation monitoring are rare (Berthinussen et al., 2014). We argue that much more knowledge is needed to devise strategies for bat-friendly forestry and make suggestions for future research directions below.

a) Although research has been done elsewhere, especially in North America, we lack long-term longitudinal studies monitoring bat population trends after logging (Law et al., 2016).

b) Quantification of direct mortality caused by forest operations is needed: if such mortality has consequences for populations, it would turn many managed forests into ecological traps (Russo et al., 2010).

c) Much information on bat ecology in forests exists, but critical practical questions posed by forest managers are left unanswered (e.g., how many suitable roost trees/ha should be saved from logging?). We need to identify factors influencing the carrying capacity of forests for bats. Best estimates, or expert judgment are often adopted in management but their consequences are rarely monitored.

d) Several studies have surveyed bat activity by using bat detectors in logged vs. unlogged forest plots (Berthinussen et al., 2014; Law et al., 2016), but observed increases in bat foraging in response to new gaps and edges created by logging need to be considered with caution: acoustic surveys overlook roost loss or mortality caused by logging. Comprehensive, standardized monitoring is needed to allow for comparisons across regions, but the huge range of existing forest types and management hampers this approach (Froidevaux et al., 2014). An important objective would be the selection of some bat species (or species groups, perhaps determined by echolocation call guilds) whose reactions might summarize responses to forestry by a wider range of taxa in the bat community, therefore acting as bioindicators. Controls (unmanaged plots) should also be monitored alongside managed plots to account for factors other than management that may be causing changes in bat activity or fitness (Cistrone et al., 2015).

e) Ideally, practices that enhance economic performance but also improve forests for bats should be identified and promoted. Management needs to move beyond mere mitigation and mimic the spatial and temporal heterogeneity of "optimal" bat habitat at multiple scales (tree cavity, tree, immediate tree surroundings, general forest habitat, and landscape). For instance, maintaining diversity in forest structure by adopting ad hoc harvesting plans and prolonging rotations would probably improve the overall carrying capacity for bats (Russo et al., 2010) and approach conditions similar to those of "optimal" forests. A landscape perspective would best negotiate the often conflicting ecological requirements of different forest bat species. An unsolved problem, however, is how to select "optimal" reference situations? Assuming these are represented by unmanaged forest is at best simplistic, at worst wrong.

f) Comparative studies on how bats exploit differently managed or unmanaged forest are important, but selecting appropriate variables to assess bat activity and fitness proxies under different conditions is not trivial. Ideally, reproductive output or fitness should be measured, but this is difficult for bats in general and especially forest species, given their elusiveness and high mobility. High-quality, long-term individual data collected by radiotracking are valuable, but such studies are still constrained by the short lifespan of the batteries in small radio-transmitters. Tag performances will hopefully improve in the future perhaps by further miniaturization or by using inter-connected data networks (Ripperger et al., 2016). The use of miniature GPS tags would also facilitate studies on habitat and roost selection by forest bats.

g) We also argue that research results should eventually lead to predictive tools to inform forest managers. For instance, an applied tool based on statistical models might support foresters in selecting the most "bat-friendly" forestry options. 
This might be developed employing state-of-art modeling, and models should be trained and validated with high quality data.

h) Several studies-geographically biased toward temperate countries, especially North America (Maine and Boyles, 2015)-have addressed pest suppression by bats in agricultural systems. Forests are also vulnerable to arthropod pests. In this context, bats may provide relevant ecosystem services as predators (Kunz et al., 2011). This issue is little investigated despite its importance to make foresters more aware of the value of bats in forests. Some exclusion studies (in which the effects of pests on plots from which bats are experimentally excluded are compared with those on control plots) show that bats are effective controllers of forest pests (e.g., Morrison and Lindell, 2012; Maas et al., 2013) but more are needed to quantify the economic value of bats in forests as has been done for agroecosystems (Maine and Boyles, 2015). Dietary studies have long been constrained by the coarse taxonomic resolution of morphological identification of prey remains (Zeale et al., 2011) but developments in metagenomics and metabarcoding permit finer resolution of prey items, allowing determination of which insect pests are consumed by insectivorous bats.

\section{CONCLUSIONS}

Forestry can lead to dramatic changes in forest structure, creating both problems but also opportunities for bat conservation. Overall, a potentially positive future for the management of bats that simultaneously benefits forestry is foreseeable, provided some fundamental steps in research and subsequent management

\section{REFERENCES}

Altringham, J. (2011). Bats. From Evolution to Conservation. New York, NY: Oxford University Press.

Anonymous (2005). Woodland Management for Bats. Wetherby, West Yorkshire, UK: Forestry Commission for England and Wales, Bat Conservation Trust, Countryside Council for Wales and English Nature.

Bartonička, T., Bielik, A., and Řehák, Z. (2008). Roost switching and activity patterns in the soprano pipistrelle, Pipistrellus pygmaeus, during lactation. Ann. Zool. Fenn. 45, 503-512. doi: 10.5735/086.045.0605

Bartonička, T., and Gaisler, J. (2007). Seasonal dynamics in the numbers of parasitic bugs (Heteroptera, Cimicidae): a possible cause of roost switching in bats (Chiroptera, Vespertilionidae). Parasitol. Res. 100, 1323-1330. doi: 10.1007/s00436-006-0414-6

Bauhus, J., Puettmann, K., and Messier, C. (2009). Silviculture for old-growth attributes. Forest Ecol. Manag. 258, 525-537. doi: 10.1016/j.foreco.2009. 01.053

Berthinussen, A., Richardson, O. C., and Altringham, J. D. (2014). Bat Conservation - Global Evidence for the Effects of Interventions. Exeter: Pelagic Publishing.

Bogdanowicz, W., Hulva, P., Černá Bolfíková, B., Buś. M. M., Rychlicka, E., Russo, D., et al. (2015). Cryptic diversity of Italian bats and the role of the Apennine refugium in the phylogeography of the western Palaearctic. Zool. J. Linn. Soc. 174, 635-648. doi: 10.1111/zoj.12248

Boye, P., and Dietz, M. (2005). Development of Good Practice Guidelines for Woodland Management for Bats. Report to The Bat Conservation Trust, 98.

Chylarecki, P., and Selva, N. (2016). Ancient forest: spare it from clearance. Nature 530, 419. doi: $10.1038 / 530419 b$ recommendations are taken. These include a quantitative assessment of factors influencing the carrying capacity of forests for bats, as well as the development of management strategies benefitting both conservation and production. A better understanding of the economic importance of bats in suppressing insects harmful to forestry is urged, as it would also provide effective arguments to facilitate acceptance among foresters of management measures aimed at conserving bats. Finally, we highlight that although scarce, there are examples of good management of bats in forest, yet many of these examples are known by bat experts but not by practitioners who implement them. A better dialogue between these two professional groups will bridge this information gap with substantial improvement of bat conservation in managed forests.

\section{AUTHOR CONTRIBUTIONS}

DR conceived the paper. All authors contributed equally to writing up and revising the manuscript.

\section{ACKNOWLEDGMENTS}

EUROBATS kindly sponsored the workshop on sustainable forest management for bats held in The Netherlands in November 2015 from which this paper arose. Thanks to Tony Mitchell-Jones for contributing important information from the EUROBATS Intersessional Working Group on Bats and Forestry which helped to stimulate the workshop's discussion on knowledge gaps and future objectives for research on bats and forestry. The Editor and the reviewers made very useful comments which greatly helped us to improve this article.

Cistrone, L., Altea, T., Matteucci, G., Posillico, M., De Cinti, B., and Russo, D. (2015). The effect of thinning on bat activity in Italian high forests: the LIFE+ "ManFor, C.BD.” experience. Hystrix Ital. J. Mammal. 26, 125-131. doi: 10.4404/hystrix-26.2-11477

Cox, M. R., Willcox, E. V., Keyser, P. D., and Vander Yacht, A. L. (2016). Bat response to prescribed fire and overstory thinning in hardwood forest on the Cumberland Plateau, Tennessee. For. Ecol. Manage. 359, 221-231. doi: 10.1016/j.foreco.2015.09.048

Cryan, P. M., and Veilleux, J. (2007). "Migration and use of autumn, winter, and spring roosts by tree bats," in Bats in Forests: Conservation and Management, eds M. Lacki, J. Hayes, and A. Kurta (Baltimore, MD: The John Hopkins University Press), 153-175.

Dietz, C., and Kiefer, A. (2014). Die Fledermaüse Europas; Kennen, Bestimmen, Schützen. Stuttgart: Franckh-Kosmos Verlags-GmbH \& Co, K. G.

Dietz, M. (2013). "Population Ecology and Habitat Requirements of Bechstein's bat Myotis bechsteinii," in Beiträge zur Fachtagung in der Trinkkuranlage Bad Nauheim. (in German and English), ed M. Dietz (Frankfurt am Main: Zarbock $\mathrm{GmbH}$ and CompanyKG), 342.

Dietz, M., and Hörig, A. (2011). Thermoregulation of tree-dwelling temperate bats - a behavioural adaptation to force live history strategy. Folia Zool. 60, $5-16$.

Duverge, P. L., and Jones, G. (2003). "Use of farmland habitats by greater horseshoe bats," in Conservation and Conflict. Mammals and Farming in Britain, eds F. Tattersall and W. Manley (London: The Linnean Society), 64-81.

Entwistle, A. C., Racey, P. A., and Speakman, J. R. (1996). Habitat exploitation by a gleaning bat, Plecotus auritus. Philos. Trans. R. Soc. B Biol. Sci. 351, 921-931. doi: $10.1098 /$ rstb.1996.0085 
EU Commission (2007). Guidance Document on the Strict Protection of Animal Species of Community Interest Under the Habitat Directive 92/43/EEC- Final Version, Brussels.

EUROBATS (2009). Bats and Forestry. Bonn: Eurobats

European Environment Agency (2016). European Forest Ecosystems - State and Trends. EEA Report 5/2016, Luxembourg, Publications Office of the European Union, 123.

FAO (2015). State of the World's Forests 2014. Rome: FAO

Fenton, M. B., and Simmons, N. B. (2014). Bats: A World of Science and Mystery. Chicago, IL: University of Chicago Press.

Forestry Commission Scotland and Scottish Natural Heritage (2009). Forest Operations and Bats in Scotland. Edinburgh: Forestry Commission Scotland Guidance Note 35a.

Froidevaux, J. S. P., Zellweger, F., Bollmann, K., Jones, G., and Obrist, M. K. (2016). From field surveys to LiDAR: shining a light on how bats respond to forest structure. Remote Sens. Environ. 175, 242-250. doi: 10.1016/j.rse.2015. 12.038

Froidevaux, J. S. P., Zellweger, F., Bollmann, K., and Obrist, M. K. (2014). Optimizing passive acoustic sampling of bats in forests. Ecol. Evol. 4, 4690-4700. doi: 10.1002/ece3.1296

Hein, C. D., Castleberry, S. B., and Miller, K. V. (2009). Site-occupancy of bats in relation to forested corridors. For. Ecol. Manage. 257, 1200-1207. doi: 10.1016/j.foreco.2008.09.054

Jones, G., Jacobs, D. S., Kunz, T. H., Willig, M. R., and Racey, P. A. (2009). Carpe noctem: the importance of bats as bioindicators. Endanger. Species Res. 8, 93-115. doi: 10.3354/esr00182

Kerth, G., Perony, N., and Schweitzer, F. (2011). Bats are able to maintain longterm social relationships despite the high fission-fusion dynamics of their groups. Proc. R. Soc. B Biol. Sci. 278, 2761-2767. doi: 10.1098/rspb.2010. 2718

Kirby, K., and Watkins, C. (2015). Europe's Changing Forests. from Wildhood to Managed Landscapes. Croydon: CAB International, 363.

Kunz, T. H., de Torrez, E. B., Bauer, D., Lobova, T., and Fleming, T. H. (2011). Ecosystem services provided by bats. Ann. N.Y. Acad. Sci. 1223, 1-38. doi: 10.1111/j.1749-6632.2011.06004.x

Kunz, T. H., and Lumsden, L. F. (2003). "Ecology of cavity and foliage roosting bats," in Bat Ecology, eds T. H. Kunz and M. B. Fenton (Chicago, IL: University of Chicago Press), 3-89.

Lacki, M. J., Amelon, S. K., and Baker, M. D. (2007). "Foraging ecology of bats in forests," in Bats in Forests: Conservation and Management, eds M. J. Lacki, J. P. Hayes, and A. Kurta (Baltimore, MD: The Johns Hopkins University Press), 83-127.

Law, B., Park, K. J., and Lacki, M. J. (2016). "Insectivorous bats and silviculture: balancing timber production and bat conservation," in Bats in the Anthropocene: Conservation of Bats in a Changing World, eds C. C. Voigt and T. Kingston (Cham; Heidelberg; New York, NY; Dordrecht; London: SpringerOpen), 105-150

Maas, B., Clough, Y., and Tscharntke, T. (2013). Bats and birds increase crop yield in tropical agroforestry landscapes. Ecol. Lett. 16, 1480-1487. doi: 10.1111/ele.12194

Maine, J. J., and Boyles, J. G. (2015). Bats initiate vital agroecological interactions in corn. Proc. Natl. Acad. Sci. U.S.A. 112, 12438-12443. doi: $10.1073 /$ pnas. 1505413112

Mayer, F., and von Helversen, O. (2001). Cryptic diversity in European bats. Proc. R. Soc. Lond. B 268, 1825-1832. doi: 10.1098/rspb.2001. 1744

Mering, E., and Chambers, C. L. (2014). Thinking outside the box: a review of artificial roosts for bats. Wildl. Soc. Bull. 38, 741-751. doi: 10.1002/w sb.461

Meschede, A., Güthler, W., and Boye, P. (2001). Bats in Forests. Information and recommendations for forest managers. Landschaft Lebensraum 4, 20.

Meschede, A., and Heller, K.-G. (2000). Ökologie und Schutz von Fledermäusen in Wäldern unter besonderer Berücksichtigung wandernder Arten [Ecology and conservation of bats in forests with special consideration of migratory species]. Schriftenreihe Landschaftspflege Naturschutz 66, $1-374$.

Meschede, A., Heller, K.-G., and Boye, P., (eds.) (2002). Ökologie, Wanderungen und Genetik von Fledermäusen in Wäldern - Untersuchungen als Grundlage für den Fledermausschutz [Ecology, migration, and genetics of bats in forests field studies as basis for bat conservation]. Schriftenreihe Landschaftspflege Naturschutz 71, 1-288.

Michalak, P. (2016). Ancient forest: keep the logging ban. Nature 530, 419. doi: $10.1038 / 530419$ c

Morrison, E. B., and Lindell, C. A. (2012). Birds and bats reduce insect biomass and leaf damage in tropical forest restoration sites. Ecol. Appl. 22, 1526-1534. doi: 10.1890/11-1118.1

Norberg, U. M., and Rayner, J. M. V. (1987). Ecological morphology and flight in bats (Mammalia; Chiroptera): wing adaptations, flight performance, foraging strategy and echolocation. Philos. Trans. R. Soc. Lond. 316, 335-427. doi: 10.1098/rstb.1987.0030

Patriquin, K., and Barclay, R. M. R. (2003). Foraging by bats in cleared, thinned and unharvested boreal forest. J. Appl. Ecol. 40, 646-657. doi: 10.1046/j.13652664.2003.00831.x

Popa-Lisseanu, A. G., Bontadina, F., and Ibáñez, C. (2009). Giant noctule bats face conflicting constraints between roosting and foraging in a fragmented and heterogeneous landscape. J. Zool. 278, 126-133. doi: 10.1111/j.14697998.2009.00556.x

Rachwald, A., (1992). Habitat preference and activity of the noctule bat Nyctalus noctula in the Białowieża Primeval Forest. Acta Theriol. 37, 413-422. doi: 10.4098/AT.arch.92-42

Ripperger, S. P., Josic, D., Hierold, M., Koelpin, A., Weigel, R., Hartmann, M., et al. (2016). Automated proximity sensing in small vertebrates: design of miniaturized sensor nodes and first field tests in bats. Ecol. Evol. 6, 2179-2189. doi: 10.1002/ece3.2040

Ruczyński, I., and Bogdanowicz, W. (2005). Roost cavity selection by Nyctalus noctula and N. leisleri (Vespertilionidae, Chiroptera) in Białowieża Primeval Forest, eastern Poland. J. Mammal. 86, 921-930. doi: 10.1644/15451542(2005)86[921:RCSBNN]2.0.CO;2

Ruczyński, I., Nicholls, B., MacLeod, C. D., and Racey, P. A. (2010). Selection of roosting habitats by Nyctalus noctula and Nyctalus leisleri in Białowieża Forest adaptive response to forest management? For. Ecol. Manage. 259, 1633-1641. doi: 10.1016/j.foreco.2010.01.041

Russo, D. (2012). "Forest degradation and bats," in Proceedings of the International Symposium on the Importance of Bats as Bioindicators, eds C. Flaquer and X. Puig-Montserrat (Granollers: Museum of Natural Sciences Edicions).

Russo, D., Cistrone, L., and Garonna, A. P. (2011). Habitat selection in the highly endangered beetle Rosalia alpina: a multiple spatial scale assessment. J. Insect Conserv. 15, 685-693. doi: 10.1007/s10841-010-9 366-3

Russo, D., Cistrone, L., Garonna, A. P., and Jones, G. (2010). Reconsidering the importance of harvested forests for the conservation of tree-dwelling bats. Biodivers. Conserv. 9, 2501-2515. doi: 10.1007/s10531-010-9 856-3

Russo, D., Cistrone, L., and Jones, G. (2005). Spatial and temporal patterns of roost use by tree-dwelling barbastelle bats, Barbastella barbastellus. Ecography 28, 769-776. doi: 10.1111/j.2005.0906-7590.04343.x

Russo, D., Cistrone, L., Jones, G., and Mazzoleni, S. (2004). Roost selection by barbastelle bats (Barbastella barbastellus, Chiroptera: Vespertilionidae) in beech woodlands of central Italy: consequences for conservation. Biol. Conserv. 117, 73-81. doi: 10.1016/S0006-3207(03) 00266-0

Russo, D., and Jones, G. (2015). Bats as bioindicators: an introduction. Mammal. Biol. 80, 157-158. doi: 10.1016/j.mambio.2015.03.005

Safi, K., and Kerth, G. (2004). A comparative analysis of specialization and extinction risk in temperate-zone bats. Cons. Biol. 18, 1293-1303. doi: 10.1111/j.1523-1739.2004.00155.x

Schnitzler, H. U., and Kalko, E. K. V. (2001). Echolocation by insect-eating bats. Bioscience 51, 557-569. doi: 10.1641/00063568(2001)051[0557:EBIEB]2.0.CO;2

Sierro, A. (1999). Habitat selection by barbastelle bats (Barbastella barbastellus) in the Swiss Alps (Valais). J. Zool. 248, 429-432. doi: 10.1111/j.14697998.1999.tb01042.x

The Council of European Communities (1992). Council Directive 92/43/EEC of 21 May 1992 on the Conservation of Natural Habitats and of Wild Fauna and Flora, Vol. 35 (L206). (Brussels: Official Journal of the European Communities), 7. 
Van der Meij, T., Van Strien, A. J., Haysom, K. A., Dekker, J. J. A., Russ, J., Biala, K., et al. (2015). Return of the bats? A prototype indicator of trends in European bat populations in underground hibernacula. Mammal. Biol. 80, 170-177. doi: 10.1016/j.mambio.2014.09.004

Voigt, C. C., and Kingston, T., (eds.) (2016). Bats in the Anthropocene: Conservation of Bats in a Changing World. (SpringerOpen), 606. doi: 10.1007/978-3-319-25220-9

WWF (2001). Insights into Europe's Forest Protection. WWF report, 35.

Zeale, M. R. K., Butlin, R. K., Barker, G. L., and Lees, D. C. (2011). Taxon-specific PCR for DNA barcoding arthropod prey in bat faeces. Mol. Ecol. Res. 11, 236-244. doi: 10.1111/j.1755-0998.2010.02920.x
Conflict of Interest Statement: The authors declare that the research was conducted in the absence of any commercial or financial relationships that could be construed as a potential conflict of interest.

Copyright () 2016 Russo, Billington, Bontadina, Dekker, Dietz, Gazaryan, Jones, Meschede, Rebelo, Reiter, Ruczyński, Tillon and Twisk. This is an open-access article distributed under the terms of the Creative Commons Attribution License (CC BY).

The use, distribution or reproduction in other forums is permitted, provided the original author(s) or licensor are credited and that the original publication in this journal is cited, in accordance with accepted academic practice. No use, distribution or reproduction is permitted which does not comply with these terms. 